\title{
Understanding the Influence of Utilitarian and Hedonic Factors on Buying Behaviour of Gen Y while Purchasing Smartphones
}

Prabha Kiran*, Terry Thomas ${ }^{\dagger}$, Jerin Johny ${ }^{\ddagger}$ and Deepak Jose§

\section{Abstract}

The paper focuses on the influence of utilitarian and hedonic factors on the buying behaviour of the Gen $Y$ consumers while purchasing smartphones. The researcher has followed a mixed method approach for the research with a descriptive research design. Primary data was collected through a survey that was conducted with 450 participants which consisted of teenagers and adults aged between 16-30 years. This collected data was then quantified using mathematical tools to come to a conclusion. Secondary data was collected from online published research articles and convenience. The influence of both these factors have a different sense of impact on every individual in the buying process, but post analysis, utilitarian factors gained primacy over hedonic factors.

Keywords: Gen Y, smartphone, purchasing, hedonic, utilitarian, buying behaviour.

\section{Introduction}

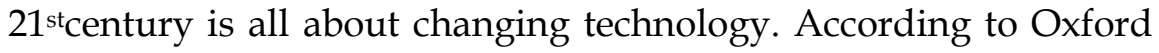
dictionary- a smartphone is "a mobile phone that performs many of

\footnotetext{
* Christ Deemed to be University (CU), Bangalore, India; prabha.kiran@christuniversity.in † (CU), Bangalore, India; terry.thomas@mba.christuniversity.in

¥ (CU), Bangalore, India; jerin.johny@mba.christuniversity.in

$\S(\mathrm{CU})$, Bangalore, India; jose.deepak@mba.christuniversity.in
} 
the functions of a computer, typically having a touch screen interface, internet access, and an operating system capable of running downloaded apps." Using smartphones has become very popular among consumers especially students and young professionals. The smartphones are becoming smarter day by day by incorporating latest technology and adding new features.They have turned in to minicomputers which one can carry in his/her pocket and can use anywhere, anytime. With smartphones one can not only just call and send messages to others but can also use internet easily and connect to social media portals like Facebook, Twitter, WhatsApp etc. along with audio-video facility and instant messaging. These features basically draw a differentiating line between ordinary mobile phones and Smartphones and make the use of smart phones easier and more user-friendly and increase its utility for the consumers.

There has been a sudden increase in the number of companies manufacturing smartphones. There is a smartphone for all the category, be it low budget phones or premium category. Online platforms like Amazon, e-bay, Flipkart, Alibaba, Taobao, NewEgg, and the likes have made shopping experience quite easy for the consumers. They can now browse through a variety of smartphones, check reviews, compare prices of the same smartphone model on various websites. This greatly influences them to purchase a smartphone. This has also helped the companies to avoid middlemen, hence a decrease inthe operational costs, which has led to smartphones now being sold at cheaper rates.

\subsection{Smartphones in India}

India, the second-most populous country in the world, was projected to pass the United States in number of smartphone users in 2017. Around 223million people in the U.S.were predicted to use a smartphone by 2017, compared to 340 million in India. Despite this increase in volume, the U.S. still has a higher smartphone penetration rate than India. The smartphone penetration rate in Indiawas forecasted to reach more than 28 percent by 2018, a penetration rate that the U.S. already reached in 2011.There were 291.6 million smartphone users in India by the end of 2017.The 
number of smartphone users in India was estimated to hit 337 million by the end of 2018. The number of smartphone users in India is predicted to reach 490.9 million by 2022. Between 2017 and 2022, the number of smartphone users in India is eastimated to grow over $60 \%$. Despite the growing trend, smartphone penetration in India will reach only $36.2 \%$ by the end of 2022 . Therefore, India portrays a big window of opportunity window for all smartphone OEMs at least for the next decade.

\section{Literature Review}

Uddin, et al. (2014) conducted a study on factors affecting buying decision of customers in Khulna city. Participants in the study were selected by convenient sampling method. Research was carried out using a structured questionnaire. Using factor analysis method, the factors affecting buying decisions were identified. Identified factors were physical attributes, followed by price, size, charging facility, operating facility, weight, recommendations of friends and colleagues and advertisements. Debadutta (2012) carried out research to find the mobile phone buying behavior of young youths in coastal districts of Odisha. Research was carried out by empirical method based on survey. The survey results were obtained by carrying out percentage test, chi-square test and Paired T-test model and revealed that people bought mobile phones in credit system. Karen Lim Lay-Yee, et al. (2013) researched on the factors affecting mobile phone purchase decision of youths in Malaysia and their association with concern for convenience, concern, product, brand, and social influence. This study revealed that marketers have to understand the purchase decision of consumers to become more competitive. Owusu Alfred (2013) conducted research on the influence of price and quality on consumer purchase in Kumasi. The data was collected through personal interview, questionnaire and pricelist of the chosen mobile phones. The study had revealed that both price and quality having high influence on consumers purchase decision. Guleria (2015) conducted research on preference of consumers for smartphones in Himachal Pradesh. The identified factor were the availability of various usability features of mobile phones. M. Aftab Uddin et al. (2015) researched on factors affecting the buying decisions of 
mobile phones. Through the literature survey, 21-item instrument was designed. Reliability, Kaiser-Mayer-Olkin (KMO) and Bartletts' tests were carried out to analyze the data collected from 432 participants. The major factors were uniqueness, social identity, brand image, physical attributes, ease of operation and price. Bhatti (2015) explored the factors influencing mobile commerce. In the research, technology acceptance model was extended. Factors such as perceived ease of use, personal innovativeness, subjective norms, behavioural control, and subjective norms were modelled. Regression analysis was used to validate the empirical data. Subjective norms, behavioral control, influence perceived ease of use were factors which were identified as being capable of affecting their purchase intention. Sujata (2016) presented a study on factors capable of affecting consumers on purchase decision. The identified factors from 306 participants were technology factors, hardware factors, basic factors, brand factors and financial factors. Pandey (2015) studied the influence of consumer's determinants on hedonic value perception for mobile phones. The study revealed that lifestyle and qualification play a key role when it comes to buying a mobile phone as educated individuals are not easy to fool with utilitarian aspects of a product. Kim et al. (2014) explored the psychological effects of screen size on smartphone adoption by proposing an extended Technology Acceptance Model (TAM). The data was collected from 130 undergraduates. It was found that screen size is a major utilitarian feature that drives consumers to buy a particular mobile.

\section{Conceptual Model}

The conceptual model of this study depends on 3 variables, i.e. hedonic factors, utilitarian factors and purchase Intention.

\subsection{Image}

There are several utilitarian factors. For smartphones, utilitarian factors has been shown to relate to the features provided by the smartphone, such as bigger screen size, larger battery capacity, rear camera quality, selfie camera quality, processor, RAM capacity, charging speed, OS updates, user interface, wireless charging, product add-ons, face unlock and fingerprint scanner (Soomro, et 
al., 2013). The utilitarian features also include the consumer's demand forfeatures (Lay-Yee et al., 2013). In general, utilitarian value has been described as instrumental, task-related, rational and cognitive.

There are several hedonic factors as well. Hedonic value, which is less studied, is more subjective and personal. It is related to the emotional needs of the consumers. Hedonic value reflects entertainment and emotional worth. It is non-instrumental, experiential and effective. For smartphones, hedonic value may be derived from brand value, social status, peer influence, social networking, reviews or the pleasure derived from communicating with others (Batra et al., 1990). It is therefore understood as the emotional benefits the customer perceives through owning the particular smartphone. Researchers have shown that mobile technologies have hedonic aspects that influence peoples' perceptions of them. The authors suggest that a person's evaluation of hedonic value of mobile technologies will influence whether they perceive them to be an opportunity or not.

In addition, what becomes important to take note of is the purchase intention. Purchase intention is the implied promise to one's self to buy the product again whenever one makes the next trip to the market (Fandos \& Flavian, 2006; Halim \& Hameed, 2005). It has a substantial significance because the companies want to increase the sale of specific products for the purpose to maximize their profit. Purchase intention portrays the impression of customer retention. Student's mobile phone purchase intention depend on their consumption experiences, consumption habit, and intuition $(\mathrm{Li}$, et al., 2010). The social influence plays an important role in deciding which brand of smartphone to purchase (Kaushal, et al., 2016).

\section{Methodology}

\subsection{Problem Statement}

In this 'technology savvy' era, it is very difficult to study, analyze and interpret consumer purchase intention. Smartphone companies are willing to financially invest in order to study their respective potential consumer's purchasing behavior. This study tries to understand the influence of Hedonic and Utilitarian factors in 
smartphone purchase intention among Gen Y consumers. Gen Y consumers are selected as they are the most tech-savvy age group, also they frequently purchase new smartphones in comparison to other age groups.

\subsection{Objective of the Study}

1. To study the influence of Hedonic Factors in purchase of smartphones among Gen Y consumers.

2. To study the influence of Utilitarian factors in purchase of smartphones among Gen Y consumers.

\subsection{Scope of the Study}

This study focuses on the Gen Y population in Indian cities like Bangalore, Delhi, Kerala, Ahmedabad, and Pune. The study includes a sample size of 450 people from various backgrounds like academics, corporates, and even homemakers. A questionnaire was used in order to conduct the survey and gather data.

\subsection{Research Methodology}

Both primary and secondary data is used in order to complete this study. Primary data collection is done through self-administered questionnaire distribution. The questionnaire is handed out by online distribution.

The majority of the respondents of the Gen Y population belong to the age category 16-18. For online distribution, it is distributed through email as well as social media platforms like WhatsApp, LinkedIn, and Facebook to people in Ahmedabad, Jaipur, Delhi and various parts of South India. It is distributed by convenient non-probability random sampling method, where respondents are chosen randomly among the targeted group.

Around 450 questionnaires were distributed online. It is received as an individual answer. The questionnaire distribution is controlled and hence no answers were biased to only one age group or gender. For secondary research, data are collected through various online literature and journals. The scope of the literature reviewed include area like consumer decision process, Smartphone in India, Generation $\mathrm{Y}$ and determinant of the purchase decision, including 
brand value, convenience, price, product feature concern and social influence. Variables derived from these literature reviews areinvestigated through primary research.

\subsection{Research Instrument}

In this research, the instrument used in primary research is questionnaire and all the questions in this questionnaire are designed in English, which is simple for respondents to understand and answer. The questions asked are directly linked to the objectives of this research. There are a total of 12 questions, which include multiple choice answers and also 5 point Likert Scale.

\subsection{Plan of Data Analysis}

The analysis was broadly classified into - Descriptive statistics, Test of adequacy of sample (KMO), Reliability tools (Decision tools like regression are used).

\subsection{Data Analysis and Interpretation}

Table 1.1 Demographic Details

\begin{tabular}{llll}
\hline & & Frequency & Percent \\
\hline Age & 16-20 years & 78 & 17.1 \\
& $21-25$ years & 297 & 65.1 \\
Gender & 26-30 years & 81 & 17.8 \\
& Male & 273 & 59.9 \\
Occupation & Female & 182 & 39.9 \\
& Student & 293 & 64.3 \\
& Private & 36 & 7.9 \\
& Professional & 107 & 23.5 \\
I purchased my & Self-employed & 15 & 3.3 \\
current smart phone & Homemaker & & \\
from & Online site & 272 & 59.6 \\
& Exclusive Brand Outlet & 82 & 18 \\
When I purchased & Electronic Store (Reliance & 41 & 11.6 \\
my current smart & Digital, Croma) & & 9 \\
phone, I got the & Online Reviews & 222 & 48.7 \\
information from: & Peer Recommendation & 115 & 25.2 \\
Current Smartphone & Advertisements & 38 & 8.3 \\
Brand & Mobile Retail Store & 36 & 7.9 \\
& Mobile Phone Website & 33 & 7.2 \\
& Other brands & 13 & 2.9 \\
& Apple & 51 & 11.2
\end{tabular}




\begin{tabular}{|c|c|c|c|}
\hline & Samsung & 66 & 14.5 \\
\hline & One plus & 44 & 9.6 \\
\hline & Motorola & 55 & 12.1 \\
\hline & Xiaomi & 109 & 23.9 \\
\hline & Vivo & 8 & 1.8 \\
\hline & Oppo & 21 & 4.6 \\
\hline & Poco & 9 & 2.0 \\
\hline & Nokia & 14 & 3.1 \\
\hline & Asus & 13 & 2.9 \\
\hline & Google & 6 & 1.3 \\
\hline & Honor & 18 & 3.9 \\
\hline & Lenovo & 14 & 3.1 \\
\hline & Huawei & 6 & 1.3 \\
\hline & HTC & 1 & .2 \\
\hline & Sony & 2 & .4 \\
\hline & Apple & 124 & 27.2 \\
\hline & Samsung & 40 & 8.8 \\
\hline & Oneplus & 152 & 33.3 \\
\hline & Motorola & 16 & 3.5 \\
\hline & Xiaomi & 47 & 10.3 \\
\hline & Vivo & 6 & 1.3 \\
\hline Future Smartphone & Oppo & 5 & 1.1 \\
\hline Brand & Poco & 11 & 2.4 \\
\hline & Nokia & 12 & 2.6 \\
\hline & Asus & 6 & 1.3 \\
\hline & Google & 22 & 4.8 \\
\hline & Honor & 4 & .9 \\
\hline & Lenovo & 2 & .4 \\
\hline & Huawei & 1 & .2 \\
\hline
\end{tabular}

Table 1.2 Case Processing Summary

\begin{tabular}{llll}
\hline & & $\mathrm{N}$ & $\%$ \\
\hline Cases & Valid & 456 & 100.0 \\
& Excluded & 0 & 0.0 \\
& Total & 456 & 100.0 \\
\hline
\end{tabular}

Table 1.3 Reliability Statistics

\begin{tabular}{ll}
\hline Cronbach's Alpha & No. of Items \\
\hline 0.961 & 28 \\
\hline
\end{tabular}


The overall alpha value is .961 which shows the data collected is from a reliable source and also indicates good internal consistency among the data collected. The reliability analysis was conducted by computing the Cronbach's alpha (a) for each moderating variables The Cronbach alpha for dependent variable (28 items) or independent variables measure 0.892 indicating that the measures have acceptable internal consistency

Table 1.4 KMO and Bartlett's Test

\begin{tabular}{lll}
\hline Kaiser-Meyer-Olkin Measure of Sampling & .958 \\
\hline Bartlett's Test of Sphericity & Approx. Chi Square & 10318.168 \\
& df & 378 \\
& Sig. & 0.000 \\
\hline
\end{tabular}

The KMO has given the significance level of 0.958 which informs that the data collected is appropriate to do a factor analysis, which will indicate the suitability of our data and proportion of variance in our variables selected for the proposed model. The KMO statistic of 0.958 is also large (greater than 0.50). Hence, Factor Analysis is considered as an appropriate technique for further analysis of the data.

\section{Hypothesis}

$\mathrm{H} 0$ : there is no significant impact of utilitarian factors on purchase intention

H1: there isno significant impact of utilitarian factors on purchase intention

Table 1.5 ANOVA Table for utilitarian factors

Anova

\section{Utilitarian}

\begin{tabular}{llllcl}
\hline & Sum of Squares & \multicolumn{1}{c}{ Df } & Mean Square & F & Sig. \\
\hline Between Groups & 226.010 & 20 & 11.301 & 28.391 & .000 \\
Within Groups & 173.145 & 435 & .398 & & \\
Total & 399.156 & 455 & & & \\
\hline
\end{tabular}

The groups considered here are utilitarian factors and their impact on purchase intention, and as the significance level is less than 0.05 it suggests that these utilitarian factors have a significant impact on consumer's purchase intention. 
$\mathrm{H} 0$ : there is no significant impact of hedonic factors on purchase intention

H1: there is a significant impact of hedonic factors on purchase intention

Table 1.6 ANOVA Table for hedonic factors

\section{ANOVA}

\section{Hedonic}

\begin{tabular}{llllll}
\hline & Sum of Squares & \multicolumn{1}{c}{ Df } & Mean Square & F & Sig. \\
\hline Between Groups & 194.667 & 20 & 9.733 & 24.656 & .000 \\
Within Groups & 171.720 & 435 & .395 & & \\
Total & 366.386 & 455 & & & \\
\hline
\end{tabular}

The groups considered here are hedonic factors and their impact on purchase intention, and as the significance level is less than 0.05 it informs that these hedonic factors have a significant impact on consumer's purchase intention.

\section{Regression}

Table 1.7 Variables Entered/Removed

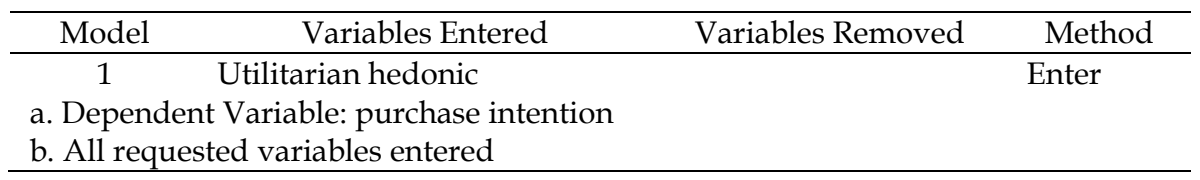

Table 1.8 Statistics

\begin{tabular}{|c|c|c|c|c|c|c|c|c|c|c|}
\hline & & & & & & Change & tati & ics & & \\
\hline $\begin{array}{l}\text { Mo } \\
\text { del }\end{array}$ & $\mathrm{R}$ & $\begin{array}{c}\mathrm{R} \\
\text { Square }\end{array}$ & $\begin{array}{c}\text { Adjus } \\
\text { ted } \mathrm{R} \\
\text { Square }\end{array}$ & $\begin{array}{c}\text { Std. } \\
\text { Error } \\
\text { of the } \\
\text { Estimate }\end{array}$ & $\begin{array}{c}\mathrm{R} \\
\text { Square } \\
\text { Change }\end{array}$ & $\begin{array}{c}\mathrm{F} \\
\text { Change }\end{array}$ & $\begin{array}{c}\mathrm{df} \\
1\end{array}$ & df 2 & $\begin{array}{c}\text { Sig. } \\
\text { F } \\
\text { Chan } \\
\text { ge }\end{array}$ & $\begin{array}{c}\text { Durbin } \\
- \\
\text { Watson }\end{array}$ \\
\hline 1 & $.758^{a}$ & .575 & .573 & .64557 & .575 & $\begin{array}{c}306 . \\
156\end{array}$ & 2 & 453 & .000 & 1.918 \\
\hline
\end{tabular}

a. Predictors: (Constant), hedonic, utilitarian

b. Dependent Variable: purchase intention

Table 1.9 Model summary

\begin{tabular}{ccccc}
\hline Model & $\mathrm{R}$ & $\mathrm{R}$ Square & Adjusted R Square & $\begin{array}{c}\text { Std. Error of the } \\
\text { Estimate }\end{array}$ \\
\hline 1 & $.758^{\mathrm{a}}$ & .575 & .573 & .64557 \\
\hline
\end{tabular}

a. Predictors: (Constant), utilitarian, hedonic 
Table. 1.10 ANOVA

\begin{tabular}{llllll}
\hline \multicolumn{1}{c}{ Model } & Sun of Squares & df & Mean Square & F & Sig. \\
\hline 1. Regression & 255.184 & 2 & 127.592 & 306.156 & $.000^{\mathrm{b}}$ \\
Residual & 188.790 & 453 & .417 & & \\
Total & 443.975 & 455 & & & \\
\hline
\end{tabular}

a. Dependent Variable: purchase intention

b. Predictors: (Constant), utilitarian, hedonic

Table. 1.11 Coefficients

\begin{tabular}{lccccc}
\hline & \multicolumn{5}{c}{$\begin{array}{c}\text { Standardized } \\
\text { Coefficients }\end{array}$} \\
\hline \multicolumn{1}{c}{ Model } & $\mathrm{B}$ & Std. Error & Beta & $\mathrm{T}$ & Sig. \\
1 (Constant) & .302 & .122 & & 2.470 & .014 \\
hedonic & .408 & .055 & .371 & 7.401 & .000 \\
utilitarian & .453 & .053 & .430 & 8.580 & .000 \\
\hline
\end{tabular}

a. Dependent Variable: purchase intention

From ANOVA analysis, the authors examine the null hypothesis, i.e. there is no impact of the independent variables on the dependent variables against the alternate hypothesis. i.e. the factors like utilitarian and hedonic have a significant impact on the purchase intention of the consumer when it comes to buying a smartphone.

P-value from the ANOVA table is 0.000 which is lesser than the significance $5 \%$ and this implies a failure to accept the alternate hypothesis and say that there exists a significant impact of the utilitarian and hedonic factors in influencing the purchase intentions.

The adjusted R2 value 0.573 means that the regression analysis can explain $57.3 \%$ of the data. The utilitarian and hedonic factors vary with purchase intentions of consumers. The P-value 0.000 is lesser than significance value and thus the authorsdecline the null hypothesis and accept alternate hypothesis which in this case is factors like, the utilitarian and hedonic factors and does have an impact on purchase intentions of the consumers. The beta value for utilitarian factors are higher than the beta value of hedonic factors which suggests that the utilitarian factors have more impact on the purchase intention of a particular consumer. 


\section{General Discussion and Implication}

The studies reported here quite clearly indicate that attitudes towards purchase intention have at least two distinct components, hedonic and utilitarian. Gen Y population ismore adaptable towards technology and hence the study mainly focuses on them. A questionnaire was circulated and responses were collected which were considered as primary data. The study has registered 450 responses. The questionnaire has covered all the basic topics like price, social concern, brand value, features etc. The data obtained was analysed using statistical tools like SPSS and Excel. Methods such as descriptive analysis for demographics, Cronbach's Alpha for reliability, ANNOVA test for checking Hypothesis, Regression Analysis for final factors analysis, and KMO and Bartlett's Test for checking the stability of the data. Initially the data showed that both utilitarian and hedonic features played an important role in purchasing a smartphone. But with more analysis, the data suggested that utilitarian factors are more influencing while purchasing smartphones.

The findings from the paper are important for both researchers and practitioners as this model can be used to understand how each individuals' decisions are affected by either utilitarian or hedonic factors of a smartphone. In this dynamic market where hundreds of smartphone brands exist and how one brand can withstand the existing competition and also outshine amongst all the other brands can be understood by this model. Gen $\mathrm{Y}$ is now not only looking for less price of the smartphone but also want something other than that, some may want better features or brand value and some may even be influenced by the person endorsing the product and few may need a combination of all these, so companies have to develop strategies to attract their customers and also strategically place their product in people's minds so that the next time they select a smartphone, the first brand which comes to their mind must be theirs. Based on that, manufacturer plans should ensure the best combinations of all utilitarian factors that benefit and satisfy customer's needs, which in turn informs and stimulates them to become involved in long-term relationships. Also, the framework enables managers to determine which behaviour elements have the greatest impact on customer retention behaviour 
and how they should plan to improve particular customer retention elements to control and maintain a specific behaviour which they hope their customers will repeat. From another point of view, the model can help suppliers not only to control but also manipulate consumer behaviour settings and consequences. As the utilitarian factors have a greater impact, companies can focus more on the features of the smartphone as some consumersare more inclined towards the camera features, some want better speed and some need a better charging capacity, so companies must try to provide all these factors together at a reasonable price because at the end price plays a major role in selecting a phone.This will provide the customers value for their money and also will give them a product which will meet all their needs. This intent will help the companies to increase their brand value and market presence and will them create trust in the customer's mind, thus facilitating the hedonic part of the study.

\section{Conclusion}

From the survey conducted, it was observed that the Utilitarian factors play a more significant role in influencing the purchasing behaviour of an individual over Hedonic factors. The results suggest that the features of a phone like screen size, processor performance, and body colour play a vital role in selecting a mobile brand which gives consumers a more affiliated feeling while using a mobile phone along with the brand value. After the research analysis, the most preferred brand was found to be Xiaomi smartphones which provide numerous features along with a reasonable price which motivates the consumer to purchase this particular brand. Hence once can predict that though hedonic factors do have some influence over consumers when buying a mobile phone but utilitarian factors have an upper hand when it comes to the final decision making and thus proving it to be the vital influencing factor in consumer's purchase intentions.

\section{References}

Adhikari, N. S. (2018). Effectiveness of advertising and sales promotion on buying decision of smartphones in Kathmandu Valley. Journal of 
Business and Social Sciences Research, 1(2), 169. doi:10.3126/ jbssr. v1i2.20923

Alshurideh, M., Bataineh, A., Alkurdi, B., \& Alasmr, N. (2015). Factors Affect mobile phone brand choices - studying the case of Jordan universities students. International Business Research, 8(3). doi:10.5539/ibr.v8n3p141

Anish, J., \& Sengottuvelu, A. J. (2018). Social Factors influencing the smartphone purchase among the generation Z. International Journal of Human Resource Management and Research, 8(5), 1-10. doi:10.24247/ ijhrmroct 20181

Azad, N., \&Safaei, M. (2012). The impact of brand value on brand selection: case study of mobile phone selection. Management Science Letters, 2(1), 1233-1238.

Batra, R., \& Ahtola, O. T. (1991). Measuring the Hedonic and Utilitarian Sources of Consumer Attitudes. Marketing Letters, 2(2), 159-170. doi:10.1007/bf00436035

Karjaluoto, H., Karvonen, J., Kesti, M., Koivumäki, T., Manninen, M., Pakola, J.,Salo, J. (2005). Factors affecting consumer choice of mobile phones: two studies from Finland. Journal of Euromarketing, 14(3), 5982. doi:10.1300/j037v14n03_04

Kim, K. J., \& Sundar, S. S. (2014). Does screen size matter for smartphones? Utilitarian and hedonic effects of screen size on smartphone adoption. Cyberpsychology, Behavior, and Social Networking, 17(7), 466-473.

Kim, M., \& Park, J. (2013). Mobile phone purchase and usage behaviours of early adopter groups in Korea. Behaviour \& Information Technology, 33(7), 693-703. doi:10.1080/0144929x.2013.796001

Kumari, P. (2016). Consumer brand preference towards mobile phone: effect of mobile phone attributes on purchase decision. IOSR Journal of Business and Management, 01(01), 01-10. doi:10.9790/487x-1501001010110

Li, S., \& Li, Y. (2010). An Exploration of the psychological factors influencing college students' consumption of mobile phone in west China. International Journal of Business and Management, 5(9). doi:10.5539/ijbm.v5n9p132

Pandey, A. (2014). Hedonic value perception for cellular phone: An exploratory Study of Indian consumers. IOSR Journal of Business and Management, 16(11), 29-32. doi:10.9790/487x-161142932

Petruzzellis, L. (2010). Mobile phone choice: technology versus marketing. The Brand Effect in the Italian Market. European Journal of Marketing, 44(5), 610-634. doi:10.1108/03090561011032298 
Rahman, S., \& Azhar, S. (2011). Xpressions of generation Y: perceptions of the mobile phone service industry in Pakistan. Asia Pacific Journal of Marketing and Logistics, 23(1), 91-107. doi:10.1108/13555851111100012

Sata, M. (2013). Factors affecting consumer buying behavior of mobile phone devices. Mediterranean Journal of Social Sciences. doi:10.5901/ mjss.2013.v4n12p103

Sethi, H. K. (2017). Consumer buying behavior of smart phones. International Journal of Engineering Research, 6(6). doi:10.17577/ ijertv6is060374

Sujata, J., Yatin, J., Abhijit, C., Noopur, S. \& Ruchi, D. (2016). Factors affecting smartphone purchase among indian youth: A descriptive analysis. Indian Journal of Science and Technology, 9(15).

Suki, N. M. (2013). Students' demand for smartphones. Campus-Wide Information Systems, 30(4), 236-248. doi:10.1108/cwis-03-2013-0013

Teng, L., \& Laroche, M. (2007). Building and Testing models of consumer purchase intention in competitive and multicultural environments. Journal of Business Research, 60(3), 260-268. doi:10.1016/ j.jbusres.2006.09.028

Tsang, M. M., Ho, S., \& Liang, T. (2004). Consumer attitudes toward mobile advertising: An empirical study. International Journal of Electronic Commerce, 8(3), 65-78. doi:10.1080/10864415.2004.11044301

$\mathrm{Xu}, \mathrm{X}$. , \& Ren, L. (2010). The influence of values and lifestyle on purchasing behavior of consumers -a research in mobile phone market. 2010 International Conference on E-Product E-Service and EEntertainment. doi:10.1109/iceee.2010.5660577 